\title{
Fibrolytic enzymes improve growth of steers fed forage-based diets
}

\author{
KA Beauchemin, L M Rode, VJH Sewalt
}

Research Centre, Agriculture and Agri-Food Canada, PO Box 3000, Lethbridge, AB, T1J 4B1, Canada

Enzymes have been used to improve the nutritive value of feeds for monogastric animals and as silage additives for ruminants. There is limited information regarding the efficacy of including fibrolytic enzymes as direct-fed additives for ruminants. The objectives of this study were to establish whether fibrolytic enzyme additives can enhance performance of growing steers, and to determine optimal enzyme concentrations in forage diets.

Crossbred beef steers $(300 \mathrm{~kg})$ were housed in individual feeding pens and offered one of three forage diets (24 animals/diet) for a period of $98 \mathrm{~d}$. Forages were alfalfa hay, timothy hay, and whole crop barley silage. A xylanase (activity measured as International Units ; IU) and a cellulase (activity measured as filter paper units ; FPU) were added at incremental levels $/ \mathrm{kg}$ DM. Levels (IU, FPU) were : 0) 0, 0 ; 1) 900,37 ; 2) 1800,74 ; 3) 3600,148 ; 4) 7200,296 ; and 5) 14400, 592. Hays were chopped and cubed $(5 \times 5 \times 3 \mathrm{~cm})$ and enzymes were added during the cubing process whereas for barley silage, enzymes were added immediately prior to feeding. Protein/mineral supplements were added to each diet to provide a minimum of $12 \%$ crude protein, and adequate rumen undegradable protein, minerals and vitamins. Animais were offered feed once per day at $110 \%$ of voluntary intake and weighed bi-weekly to determine average daily gain (ADG; kg/d) using a regression approach.

The ADG was enhanced by enzyme addition for alfalfa $(P=0.15)$ and timothy cubes $(P=0.065)$, but not $(P=0.67)$ for barley silage. For alfalfa, ADG increased with low levels of fibrolytic enzymes and declined thereafter, whereas for timothy, maximum ADG occurred at the highest enzyme concentration. Enzyme additives only affected dry matter intake (DMI) of timothy hay $(P=0.03)$; animals receiving the highest enzyme level had higher $(P=0.04)$ DMI than for other enzyme levels.

This study suggests that fibrolytic enzymes improve animal performance when applied to dry forages but the optimum enzyme level is dependent upon the type of forage. Studies are in progress to explain why responses differed among forages.

\begin{tabular}{|c|c|c|c|c|c|c|c|c|}
\hline \multirow[t]{2}{*}{ Forage } & \multirow[t]{2}{*}{ Item } & \multicolumn{6}{|c|}{ Enzyme Level } & \multirow[b]{2}{*}{ SE } \\
\hline & & 0 & 1 & 2 & 3 & 4 & 5 & \\
\hline \multirow{2}{*}{ Alfalfa } & ADG & 1.03 & 1.27 & 1.28 & 1.34 & 1.19 & 1.11 & 0.09 \\
\hline & DMI & 10.2 & 10.8 & 10.6 & 11.5 & 11.1 & 10.3 & 0.7 \\
\hline \multirow{2}{*}{ Timothy } & ADG & 1.22 & 1.31 & 1.12 & 1.24 & 1.27 & 1.66 & 0.12 \\
\hline & DMI & 8.8 & 8.3 & 7.5 & 9.3 & 8.6 & 9.4 & 0.4 \\
\hline \multirow[t]{2}{*}{ Barley silage } & ADG & 1.11 & 1.16 & 0.99 & 1.03 & 1.11 & 1.12 & 0.08 \\
\hline & DMI & 7.4 & 8.2 & 6.8 & 7.9 & 7.0 & 7.4 & 0.4 \\
\hline
\end{tabular}

